\title{
Survival features of EBV-stabilized cells from centenarians: morpho-functional and transcriptomic analyses
}

\author{
Paola Matarrese • Antonella Tinari • Barbara Ascione • Lucrezia Gambardella • \\ Daniel Remondini • Stefano Salvioli • Elena Tenedini • Enrico Tagliafico • \\ Claudio Franceschi $\cdot$ Walter Malorni
}

Received: 8 April 2011 /Accepted: 19 August 2011 /Published online: 9 September 2011

(C) The Author(s) 2011. This article is published with open access at Springerlink.com

\begin{abstract}
In the present work, we analyzed the survival features of six different Epstein-Barr virus (EBV)-stabilized lymphoid cell lines obtained from adult subjects and from subjects of more than 95 years. For the first, we found that lymphoid B
\end{abstract}

Electronic supplementary material The online version of this article (doi:10.1007/s11357-011-9307-4) contains

supplementary material, which is available to authorized users.

P. Matarrese - B. Ascione - L. Gambardella $\cdot$ W. Malorni Department of Drug Therapy and Medicine Evaluation, Istituto Superiore di Sanità,

Rome, Italy

P. Matarrese

Center of Metabolomics,

Rome, Italy

A. Tinari

Department of Technology and Health, Istituto Superiore di Sanità,

Rome, Italy

D. Remondini

Department of Physics, University of Bologna,

Bologna, Italy

D. Remondini $\cdot$ S. Salvioli $\cdot$ C. Franceschi

Interdepartmental Centre "L. Galvani" (C.I.G.),

Bologna, Italy

S. Salvioli $\cdot$ C. Franceschi

Department of Experimental Pathology,

University of Bologna,

Bologna, Italy cells from centenarians were more resistant to apoptosis induction and displayed a more developed lysosomal compartment, the most critical component of phagic machinery, in comparison with lymphoid B cells from adult subjects. In addition, cells from

S. Salvioli $\cdot$ E. Tenedini $\cdot$ E. Tagliafico $\cdot$ C. Franceschi BioPharmaNet, Emilia-Romagna High-Tech Network, Ferrara, Italy

E. Tenedini $\cdot$ E. Tagliafico

Department of Biomedical Sciences,

University of Modena and Reggio Emilia,

Modena, Italy

E. Tenedini $\cdot$ E. Tagliafico

Center for Genome Research,

University of Modena and Reggio Emilia,

Modena, Italy

W. Malorni

Istituto San Raffaele Sulmona,

L'Aquila, Italy

W. Malorni $(\bowtie)$

Section of Cell Aging and Degeneration,

Department of Therapeutic

Research and Medicine Evaluation,

Istituto Superiore di Sanita',

viale Regina Elena 299,

00161 Rome, Italy

e-mail: malorni@iss.it 
centenarians were capable of engulfing and digesting other cells, i.e., their siblings (even entire cells), whereas lymphoid cells from "control samples", i.e., from adults, did not. This behavior was improved by nutrient deprivation but, strikingly, it was unaffected by the autophagy-modulating drug, rapamycin, an autophagy inducer, and 3-methyladenine, an autophagy inhibitor. Transcriptomic analyses indicated that: (1) aspartyl proteases, (2) cell surface molecules such as integrins and cadherins, and (3) some components of cytoskeletal network could contribute to establish this survival phenotype. Also, Kyoto Encyclopedia of Genes and Genomes pathways such as Wnt signaling pathway, an essential contributor to cell migration and actin cytoskeleton remodeling, appeared as prominent. Although we cannot rule out the possibility that EBV-immortalization could play a role, since we observed this phagic behavior in cells from centenarians but not in those from adults, we hypothesize that it may represent an important survival determinant in cells from centenarians.

Keywords Lymphoid cells · Centenarians ·

Apoptosis · Cannibalism · Autophagy · Transcriptomic analysis

$\begin{array}{ll}\text { Abbreviations } \\ \text { 2DG } & \text { 2-Deoxy-D-glucose } \\ \text { 3-MA } & \text { 3-Methyladenine } \\ \text { AV } & \text { Annexin V } \\ \text { DHE } & \text { Dihydroethidium } \\ \text { EBV } & \text { Epstein-Barr virus } \\ \text { HC } & \text { Homo-cannibalism } \\ \text { IVM } & \text { Intensified video microscopy } \\ \text { JC1 } & \text { 5-5',6-6'-Tetrachloro-1,1',3, } \\ & \text { 3'-tetraethylbenzimidazol-carbocyanine } \\ & \text { iodide } \\ \text { KEGG } & \text { Kyoto Encyclopedia of Genes and } \\ & \text { Genomes } \\ \text { K/S } & \text { Kolmogorov-Smirnov } \\ \text { Lcs } & \text { Lymphoblastoid cells } \\ \text { LTR } & \text { LysoTracker } \\ \text { MDC } & \text { Monodansylcadaverine } \\ \text { MMHP } & \text { Mitochondrial membrane hyperpolarization } \\ \text { MMP } & \text { Mitochondrial membrane potential } \\ \text { PHA } & \text { Phytohemagglutinin } \\ \text { RA } & \text { Rapamycin } \\ \text { ROS } & \text { Reactive oxygen species } \\ \text { SD } & \text { Standard deviation }\end{array}$

SRV Starvation

STS Staurosporine

TB Trypan blue

TEM Transmission electron microscopy

\section{Introduction}

Autophagy was initially considered as a cell death mechanism (called type II programmed cell death) characterized by the presence of an abnormal (auto) phagic behavior exerted by non-professional phagocytes that engulf and digest organelles and other materials. However, autophagy has more recently been defined as a sort of housekeeping behavior that allows the cells to recycle all wasted debris and actually represents a survival option rather than a cell death mechanism (Yang and Klionsky 2010). Autophagy is characterized by sequestration of cytoplasmic structures or organelles in double-membraned vesicles called autophagosomes that subsequently fuse with lysosomes, leading to degradation of their content. This process, also called self-cannibalism, is important for cellular homeostasis and represents a survival response, which is upregulated in response to metabolic stress or to nutrient deprivation (Moreau et al. 2010). Moreover, it is nowadays assumed that disturbances of autophagy play key roles in a number of human diseases, including metabolic, degenerative, and autoimmune diseases (Mehrpour et al. 2010). Furthermore, it has also been considered as a mechanism of cellular resistance, since cells undergoing autophagy escape from drug-induced apoptosis, e.g., in cancer, and survive (Chen et al. 2010). Hence, it has been suggested that cell susceptibility to proapoptotic stimulation could at least partially be counteracted by autophagic machinery. As senescence is concerned, at the cellular level, it is considered a separate issue with respect to autophagy, senescence being an irreversible phenomenon and autophagy a transient one (Madeo et al. 2010). On the other hand, at the organism level, although it is well known that apoptotic susceptibility varies with age, no information is still available as concerns the susceptibility to autophagy in cells from aged subjects (Salvioli et al. 2008).

However, a further clue has also derived from recent studies: it concerns the ability of certain cells to develop a peculiar process that was considered as 
parallel to autophagy/self-cannibalism and was called xenophagy ("eat foreign matter") or xenocannibalism (Matarrese et al. 2008). This process was "historically" associated with infections by both viral and bacterial agents that are entrapped in phagic vacuoles (Levine 2005). These agents can then escape from their disruption by subverting host cell autophagic flux and the completion of the autophagic process (Orvedahl and Levine 2008). Likewise, phagic vacuoles can also contain remnants and debris derived from the engulfment of other cells. This process was named xeno-cannibalism or entosis (Mormone et al. 2006; Overholtzer and Brugge 2008). For instance, the ability of a nonprofessional phagocytic cell to internalize other cells as well as genetically identical cells (siblings) has been described since many years and can pertain to various cell types, especially under metabolic stress (Overholtzer and Brugge 2008). It can finally lead to the digestion of the engulfed cell in huge (auto) phagic vacuoles and to the survival of the cannibal cell. Indeed, it was hypothesized that, under starvation, or when mitochondria energy metabolism is impaired, cannibalism could contribute to cell survival (Matarrese et al. 2008). This "aggressive" fratricidal behavior was hypothesized to represent an exacerbation of autophagy and was strikingly observed in different cell types, including transformed and non-transformed cells (Matarrese et al. 2008; Malorni et al. 2007; Tinari et al. 2008; Lai et al. 2010). On these bases, we decided to evaluate the susceptibility to apoptosis and autophagy of lymphoid cells from adult healthy donors and from centenarians. These represent a very select population of individuals undergoing successful aging that have widely been investigated from an immunological point of view (Sansoni et al. 2008). For instance, the features of lymphocytes from centenarians in terms of susceptibility to apoptosis have been investigated elsewhere (Monti et al. 2000). In the present work, we report that, in response to metabolic stress, lymphoblastoid cells (Lcs) from centenarians appear highly resistant to pro-apoptotic stimulation. The most surprising results that we observed were however associated with the ability of a sub-population of these Lcs from centenarians to cannibalize their siblings, a phenomenon which was undetectable in Lcs from adult healthy donors.

\section{Materials and methods}

Cell cultures Lymphocytes were obtained from peripheral blood of voluntary subjects of different ages: three adult subjects (aged $40 \pm 10$ years) and three centenarian subjects (aged 95-102 years). The lymphocytes were immortalized by infection with Epstein-Barr virus (Olivieri et al. 2003). Briefly, cell lines were established from freshly isolated lymphocytes or from cryopreserved lymphocytes using standard Epstein-Barr virus (EBV) transformation protocols that include cell separation by gradient centrifugation and lymphocyte growth enhancement by the mitogen PHA. Cell lines were established in the absence of antibiotics and then maintained in RPMI-1640 medium supplemented with 10\% fetal bovine serum (FBS, GBCO) and penicillin/streptomycin (100 mg/ml, EuroClone, Milan, Italy). In consideration of the alterations occurring upon extended culture periods in EBV-immortalized cell lines, all cell lines were kept in culture for less than 1 month. After this period, a further cell vial, maintained in liquid nitrogen, was thawed and cultured.

Characterization of cell lines Surface expression pattern of some molecules characterizing EBVtransformed lymphocytes (CD3, CD20, CD38) (Becton Dickinson, BD, Mountain View, CA, USA) or of molecules of importance in determining cell death (CD95/Fas, TNFR1a, TNFR1b, Fas Ligand) (Caltag Medsytems, Little Balmer Buckingham, UK) have been evaluated by flow cytometry (see Supplementary Table 1). In addition, the expression of CD93 and CD68 (BD) was also evaluated. These analyses were carried out at $4^{\circ} \mathrm{C}$ by using specific fluorochromeconjugated monoclonal antibodies (all by BD). Cell growth and cell cycle progression analysis was also performed in all cell lines. Statistical analysis of these data failed to reveal any significant difference between lymphocytes obtained from adult voluntary subjects and centenarian subjects. All cytometric analyses were performed on a Facscan flow cytometer (BD) equipped with a 488-nm Argon laser. Samples were acquired in list mode, for each sample a minimum of 20,000 cells were acquired and analyzed.

Cell death induction and evaluation Cells $\left(5 \times 10^{5} \mathrm{ml}^{-1}\right)$ were seeded into multi-well plates and treated as 
follows: (1) with $1 \mu \mathrm{M}$ staurosporine (STS, Sigma, St. Louis, MO, USA) for $18 \mathrm{~h}$ or (2) withdrawal of growth factors (serum starvation (SRV)) for 5 days. Both treatments were also performed in cells preincubated for $2 \mathrm{~h}$ with 3-methyladenine (3-MA, $10 \mathrm{mM}$, Sigma) or rapamycin (RA, $50 \mathrm{nM}$, Sigma). Cells treated with 3-MA or RA alone were considered as controls. Quantitative evaluation of cell death was performed by flow cytometry using annexin V/trypan blue (MBL, Woods Hole, MA, USA).

Mitochondrial membrane potential in living cells The mitochondrial membrane potential (MMP) of control and starved lymphoblastoid cell lines was studied by using 5-5',6-6'-tetrachloro-1,1',3,3'-tetraethylbenzimidazol-carbocyanine iodide probe (JC-1; $10 \mu \mathrm{M}$, Molecular Probes, Leiden, The Netherlands). To reveal changes in the MMP, we set the instrument parameters on control untreated cells, and then we acquired all the other samples by using the same parameters. During data analysis, we arbitrarily put a region on the FL1/FL2 dot plot of control cells in correspondence to $10^{2}$ of the FL2 emission (J-aggregates). In this area are included cells with high red fluorescence emission, thus characterized by hyperpolarized mitochondria. All the other samples were analyzed maintaining in the same position the above region.

Analysis of ROS production Cells $\left(5 \times 10^{5}\right)$ were incubated with dihydroethidium (DHE, $1 \mu \mathrm{M}$, Molecular Probes) for $15 \mathrm{~min}$ at $37^{\circ} \mathrm{C}$. After this time, samples were immediately analyzed by flow cytometry.

Cytological analyses Autophagic vacuoles were labeled with the autofluorescent drug monodansylcadaverine (MDC, Sigma) by incubating cells with $0.05 \mathrm{mM} \mathrm{MDC} \mathrm{(Sigma)} \mathrm{in} \mathrm{PBS} \mathrm{at} 37^{\circ} \mathrm{C}$ for $10 \mathrm{~min}$. To evaluate, the volume of the acidic compartments were labeled by incubating the cells with $1 \mu \mathrm{M}$ LysoTracker (Molecular Probes, green) in the culture media at $37^{\circ} \mathrm{C}$ for $15 \mathrm{~min}$. Cells were analyzed by IVM or by flow cytometry.

Ultrastructural analyses For transmission electron microscopy (TEM) examination, cells were fixed in $2.5 \%$ cacodylate-buffered (TAAB; $0.2 \mathrm{M}, \mathrm{pH} 7.2$ ) glutaraldehyde (TAAB, Berks, England) for $20 \mathrm{~min}$ at room temperature and post-fixed in $1 \% \mathrm{OsO}_{4}$ (Electron Microscopy Sciences, Hatfield, PA, USA) in cacodylate buffer for $1 \mathrm{~h}$ at room temperature. Fixed specimens were dehydrated through a graded series of ethanol solutions and embedded in Agar 100 (Electron Microscopy Sciences). Ultrathin sections were collected on 200-mesh grids and counterstained with uranyl acetate (Electron Microscopy Sciences) and lead citrate. Sections were observed with a Philips 208 electron microscope at $80 \mathrm{kV}$.

Morphometric analyses Sections were analyzed by TEM to evaluate the percentage of cannibalic cells, i.e., cells engulfing entire cells (either alive or apoptotic) as well as huge cell remnants, At least 100 different cells were examined at a magnification of $\times 8,000$. Typical autophagic vacuoles were excluded by these analyses.

Gene expression analysis The Lcs were cultured in RPMI medium supplemented with $2 \mathrm{mML}$-glutamine and penicillin/streptomycin $(100 \mathrm{mg} / \mathrm{ml})$ in presence or absence of $10 \%$ FBS for $48 \mathrm{~h}$. Cells were then collected, and total cellular RNA was isolated by means of the Qiagen RNeasy Micro Kit following the manufacturer's instructions (Qiagen, Valencia, CA). Quantity and purity/integrity of each sample was quantified using the Nanodrop 1000 (Thermo Fisher Scientific, Freemont, CA, USA) and the 2100 Bioanalyzer (Agilent Technologies, Palo Alto, CA, USA). cDNA synthesis, biotin-labeled target synthesis, HG-U133A GeneChip Plus 2.0 arrays hybridization, staining, and scanning were performed according to GeneChip One-Cycle Target Labeling and Control Reagents protocol, supplied by the manufacturer (Affymetrix, Santa Clara, CA, USA). Gene expression data are publicly available at the GEO repository (http://www.ncbi.nlm.nih.gov/projects/geo/) with the GSE31040 ID.

Data analysis and statistics Statistical analyses of apoptosis were performed by using Student's $t$ test. Flow cytometry results were analyzed by using the K/S test. All data reported in this paper were verified in at least four different experiments and expressed as mean \pm standard deviation (SD). Only $p$ values of less than 0.01 were considered as significant. Concerning the analysis of gene expression arrays, the comparisons between (1) adult vs. centenarian samples 
untreated, and (2) adult vs. centenarian samples after starvation were performed with Student's $t$ test, and significant genes were chosen with a $p<0.01$ or $p<0.05$ significance threshold, depending on the analysis. The Kyoto Encyclopedia of Genes and Genomes (KEGG) pathway functional analysis was performed by means of a hypergeometric test, comparing the number of significant genes inside the pathway with the total number of significant genes in the whole array, and a $p<0.05$ threshold was considered for significance.

\section{Results}

Cell death susceptibility of immortalized lymphoblastoid cell lines

Apoptosis Epstein-Barr virus very efficiently infects human B cells resulting in immortalized lymphoid B cells. These are considered as a model to study either functional activities of $\mathrm{B}$ cells or oncogenic events involved in transformation of B cells and, also, to analyze the relevance of stress response in longevity (Marini et al. 2004). Flow cytometric analysis of cell death (Fig. 1a) clearly indicated that in standard culture conditions, i.e., in the presence of $10 \%$ FCS in the growth medium (untreated), Lcs obtained from centenarian subjects displayed lower levels of "spontaneous" apoptosis, in comparison to those observed in Lcs obtained from adult healthy donors (about $-40 \%$ ). SRV, known to induce both apoptosis and autophagy, induced a significantly higher level of apoptosis in Lcs from adult subjects with respect to Lcs from centenarians (about $+250 \%$ ), as measured by annexin V (AV) and trypan blue (TB) double staining (Codogno and Meijer 2005). Similar results were obtained by using further different apoptotic stimuli such as STS, an inhibitor of protein kinase C, or 2DG, a glucose analog that inhibits glycolysis (not shown). For autophagy analyses, see below.

Mitochondria Alterations of the MMP are present both in apoptotic and autophagic processes (Boya et al. 2005). In particular, in apoptotic cell death, the loss of MMP was considered as an event associated with the release of apoptogenic factors, i.e., apoptosis execution (Kroemer and Reed 2000). Importantly, several studies have also demonstrated that the hyperpolarization of mitochondrial membrane (MMHP), i.e., an increase of MMP, can be associated with early events of apoptosis or to a mitochondrial status influencing the commitment and the propensity to cell death (Matarrese et al. 2003; Perl et al. 2004; Giovannini et al. 2002). As concerns autophagy, the MMP loss has been associated with mitophagy, i.e., the targeted elimination of mitochondria (Narendra et al. 2009).

Flow cytometry analysis of Lcs after staining with JC-1 (Fig. 1b) revealed that SRV induced an increase of MMP in a significant percentage of cells from adult healthy donors (about $+30 \%$ vs. untreated cells) but not in Lcs from centenarians $(<3 \%$ vs. untreated cells). MMHP was accompanied by a dramatic increase of reactive oxygen species (ROS) production (about $+230 \%$ vs. untreated cells) in Lcs from adult subjects, as measured by DHE staining. Interestingly, Lcs from centenarians showed a basal level of ROS production higher than that of Lcs from adult healthy donors (about $+120 \%$ ). However, we did not find any further increase of ROS generation in cells under SRV (Fig. 1c).

Autophagy In order to better characterize the cell death type, we evaluated the activity of specific modulators of autophagy in SRV-induced cell death. To this purpose, we used RA, a mTOR inhibitor that induces autophagy, and 3-MA, a putative modulator of class III phosphatidylinositol 3-kinase that inhibits autophagy execution (Simonsen and Tooze 2009). We observed that these autophagy modulators did not influence significantly cell fate, either in adult healthy donors or in centenarians (Fig. 2a).

Lysosomal compartment In light of the results reported above, we analyzed the lysosomal/autophagosomal compartments by flow cytometry. To do this, we used monodansylcadaverine (MDC, Fig. 2b), an autofluorescent probe that has been shown to stain autophagic vacuoles, and LysoTracker (LTR, Fig. 2c), an acidophilic lysosomal probe useful to reveal changes in lysosomal volume (Biederbick et al. 1995; Boya et al. 2003). We found that Lcs from adult subjects (Fig. 2b, left panel) under serum deprivation significantly increased their positivity to MDC. As expected, cells treated with 3-MA alone significantly decreased their positivity to MDC 

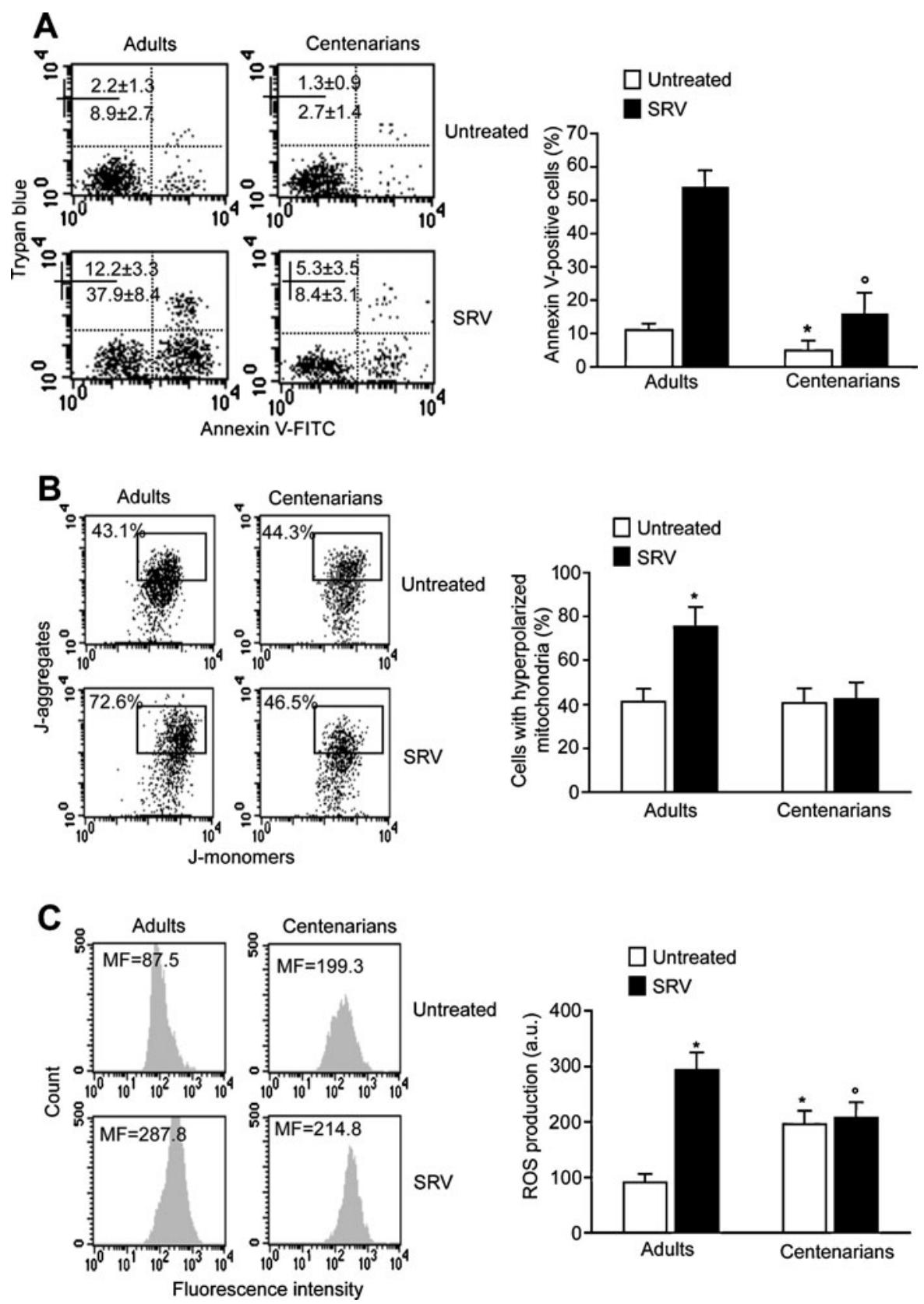

Fig. 1 a Biparametric flow cytometry analysis of apoptosis after double staining of cells with annexin V-FITC/TB. Dot plots from a representative experiment are shown in the left panels. Numbers represent the percentage of annexin V-single positive cells (early apoptosis, upper right quadrant) or annexin V/trypan blue-double positive cells (late apoptosis, lower right quadrant). In the right panel, histogram showing results obtained from three independent experiments presented as mean \pm SD are reported. ${ }^{*} p<0.01$ vs. untreated adults; open circle $p<0.01$ vs. adults SRV. b Biparametric flow cytometry analysis of MMP after staining with JC-1. Numbers reported in the boxed area represent the percentages of cells with hyper- polarized mitochondria. Results obtained in a representative experiment are shown in the left panels. In the right panel, the means $\pm \mathrm{SD}$ of the percentages of cells with hyperpolarized mitochondria, obtained from four different experiments, are shown. ${ }^{*} p<0.01 v s$. untreated adults. c Quantitative flow cytometry analysis of ROS production performed by using DHE. Results obtained in a representative experiment are shown in the left panels. Values reported represent the median fluorescence. Histogram displaying the mean $\pm \mathrm{SD}$ of ROS production obtained from four different experiments is shown in the right panel. ${ }^{*} p<0.01 \mathrm{vs}$. untreated adults; open circle $p<0.01$ vs. untreated centenarians 
Annexin V-single positive

Annexin V/TB double- positive
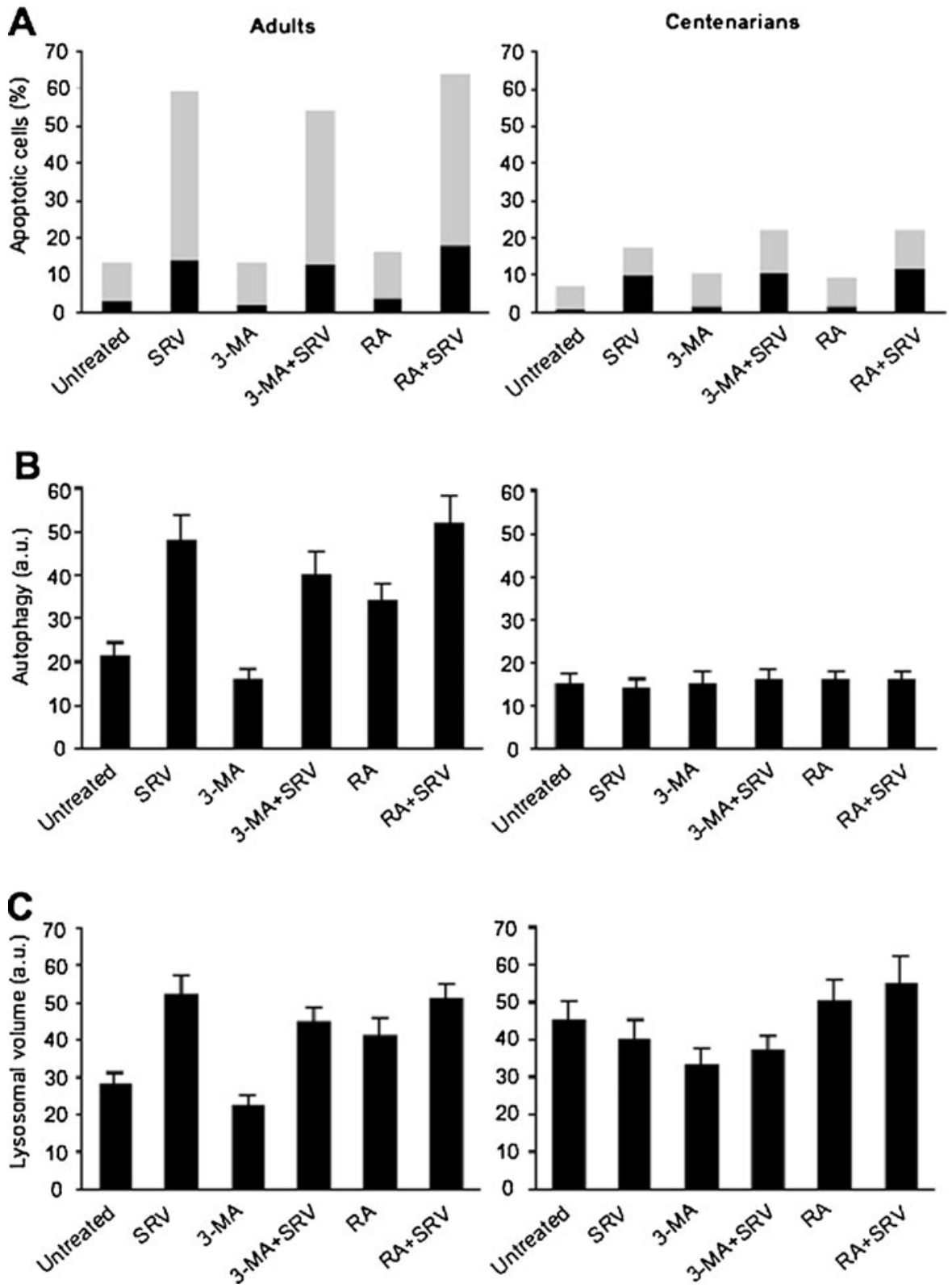

Fig. 2 a Biparametric flow cytometry analysis of apoptosis after double staining of cells with annexin V-FITC/TB. Effects exerted by the autophagic modulators 3-MA and RA on SRVinduced cell death. The histogram represents results, reported as mean $\pm \mathrm{SD}$, obtained from four independent experiments. To note: (1) the higher susceptibility to SRV-induced cell death of Lcs obtained from adult donors and (2) the inability of both 3MA and RA to modulate cell death induced by SRV. b Cytofluorimetric quantification of authophagy after cell staining with MDC. The histogram represents results, reported as mean $\pm \mathrm{SD}$, obtained from three independent experiments. Values reported represent the median fluorescence obtained in four different experiments. Note that (1) the low level of autophagy observed in Lcs obtained from centenarian subjects in comparison to those obtained from adult donors; (2) that neither 3-MA nor RA are able to modulate autophagy in Lcs from centenarians subjects. c Cytofluorimetric analysis of lysosomal compartment after cell staining with LTR green. The histogram represents results, reported as mean $\pm \mathrm{SD}$, obtained from four independent measurements. Values reported represent the median fluorescence obtained in four different experiments. To note, Lcs from centenarian subjects had a lysosomal compartment greater than cells from adult donors 
(about $-25 \%$ ) whereas RA given alone induced a significant increase of MDC positivity (about $+60 \%$ ). Similarly, the presence of 3-MA during serum starvation significantly decreased MDC-positivity (about -15\%) whereas RA increased the fluorescence emission due to MDC (about $+10 \%$ ). Interestingly, we found completely different experimental results in Lcs from centenarians (Fig. 2b, right panel). In fact, we observed a significant reduction of the MDC-positivity in untreated Lcs from centenarians ( $-30 \%$ vs. Lcs from adult subjects). In addition, we found that in cells from centenarians fluorescence emission due to MDC was influenced neither by serum starvation nor by the autophagy modulators 3-MA and RA.

Semi-quantitative cytofluorimetric analysis of lysosomal volume performed by LTR (Fig. 2c) also revealed that, in standard culture conditions, i.e., in the presence of $10 \%$ FCS in the growth medium, Lcs form centenarians showed a lysosomal compartment volume significantly greater than that of Lcs from adult subjects (about $+40 \%$ ). In agreement with data concerning MDC, we also found that in Lcs from adult subjects (1) both SRV and RA, alone or in combination, induced a significant increase of lysosomal volume, and (2) 3-MA determined a reduction of lysosomal volume, either alone or administered during serum starvation. Conversely, neither SRV nor autophagy modulators RA and 3-MA (alone or in combination) were able to induce any alteration of the volume of lysosomal compartment in Lcs from centenarians.

Morphological analyses: cannibalism

On the bases of the above results and in order to clarify the origin of such vesicles, we decided to perform a specific ultrastructural analysis by TEM in the above experimental conditions. We found that such vesicles were largely absent in Lcs from adult subjects under standard culture conditions (Fig. 3a) and under SRV, where, according to the results reported above, apoptotic cells were frequently detectable (Fig. 3b). At variance, a percentage of Lcs from centenarians presented large autophagic vacuoles under both standard conditions and SRV (Fig. 3c, d, respectively). To deep inside the nature of the observed vacuoles, we tried to modulate autophagic process via RA or 3-MA as stated above, and we analyzed the samples by TEM. As expected, we observed that RA bolstered autophagy in Lcs from adult subjects both in standard growth conditions and under SRV. Treatment with the autophagy inhibitor 3MA, which was ineffective in serum-supplemented cells (not shown), clearly impaired autophagic process in cells from adults under starvation, as predicted. However, some apoptotic cells were also observable in these samples, probably due to the lack of cytoprotective effects provided by autophagy. Importantly, in Lcs from centenarians, the presence of huge vacuoles containing mitochondria and cell remnants often seemingly engulfing foreigner material (including chromatin) was always detectable, even in the presence of the autophagy inhibitor 3-MA (Fig. 3f) or of the autophagic inducer RA (Fig. 3e). Observations performed by TEM in the presence of autophagy modulators are in accord with the data obtained by flow cytometry (Fig. 2).

However, further striking findings were derived from these analyses and are referred as to the possible implication of the ability of some cells to exert a phenomenon called cannibalism, i.e., the ability of non-professional phagocytes to engulf and digest their siblings (Fiorentini et al.). In fact, either in the presence of serum or, better, under SRV, Lcs from centenarians clearly displayed the presence of the cell-in-cell phenomenon, which was substantially undetectable in Lcs from adult people. The quantitative morphometric evaluations of these samples (carried out as stated in "Materials and methods") clearly indicated that the percentages of cells showing cannibalic activity were of about $10 \%$ in cells with FCS and significantly increased (doubled) under starvation (Table 1). The phenomenon was characterized by the presence of entire cells undergoing degeneration inside huge vacuoles (Fig. 4a). Importantly, the association of RA with starvation did not significantly modify the phenomenon, i.e., no increased percentage of cannibalic figures was detectable. When autophagy was inhibited by using 3-MA, large vacuoles containing cell debris, cell remnants, but also entire cells were still observable (Fig. 4b). In fact, the quantitative evaluation of these results clearly indicated that cannibalic activity occurred irrespective of the modulation of autophagy (Table 1). TEM analysis of the cannibalic activity in Lcs from centenarians is also reported in Fig. 5 where the different aspects of this behavior are shown as a sort 
Fig. 3 Electron micro graphs showing: a normal morphology of Lcs from adult subjects; b a representative image of an apoptotic Lcs (arrow), frequently detected in cells from adult subject under SRV; c two large autophagic vacuoles (arrows), observable in either Lcs from centenarians under standard culture conditions or d under SRV; e Lcs from centenarians after treatment with the autophagy-inducer RA, characterized by the presence of a large vacuole containing mitochondria and cell remnants. f The same vacuoles were detectable even in Lcs from centenarians after treatment with the autophagy inhibitor 3-MA
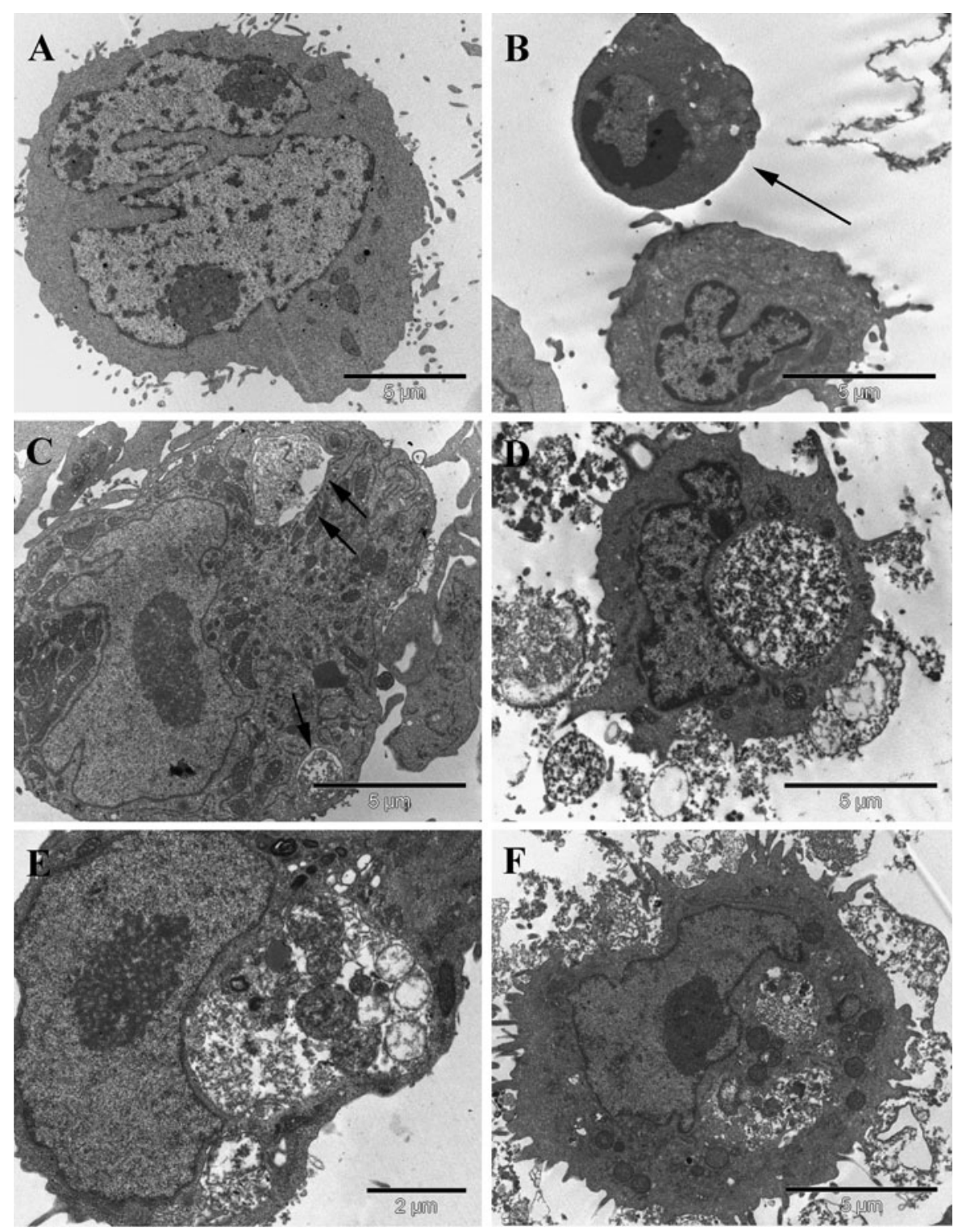

of time course. It can be characterized by: (1) an impressive polarization of the cannibalic cell towards its "victim" (Fig. 5a), an engulfment (Fig. 5b) and progressive digestion of the internalized cells (Fig. 5c, d), finally leading to the dissolution of the ingested cell (Fig. 5e).

Gene expression analysis

We analyzed the whole genome expression of Lcs cultures (three samples from adult individuals and three from centenarians) by Affimetrix HG U133 Plus 2 arrays, containing about 55,000 probes. Lcs were serum-starved for $48 \mathrm{~h}$, and before harvesting, they were checked for viability by flow cytometry. At that time, no significant level of apoptosis was detected after SRV with respect to control cells (not shown). We performed two comparisons: adult vs. centenarians at basal culture conditions and adult vs. centenarians under SRV. Three groups of genes have been identified: (1) those that significantly differ only in the first comparison but not in the second, (2) those that differ in the second comparison but not in the first, and (3) those that are significantly different in both comparisons. We reasoned that in group 1 genes responsible for age-based differences should be 
Table 1 Morphometric evaluation of cannibalic cells in centenarians $(\%)$

\begin{tabular}{lrr}
\hline & FCS + & FCS- \\
\hline Controls & $10 \pm 3$ & $15 \pm 4$ \\
Rapamycin & $11 \pm 4$ & $16 \pm 4$ \\
3-MA & $7 \pm 4$ & $12 \pm 3$ \\
\hline
\end{tabular}

The morphometric analyses indicate that SRV significantly increased cell cannibalism $(p<0.05)$ whereas treatments with autophagy modulators (3MA, rapamycin) did not modify the percentage of cannibal cells

present; group 2 should contain genes responsible for the difference in the response to SRV, and group 3,

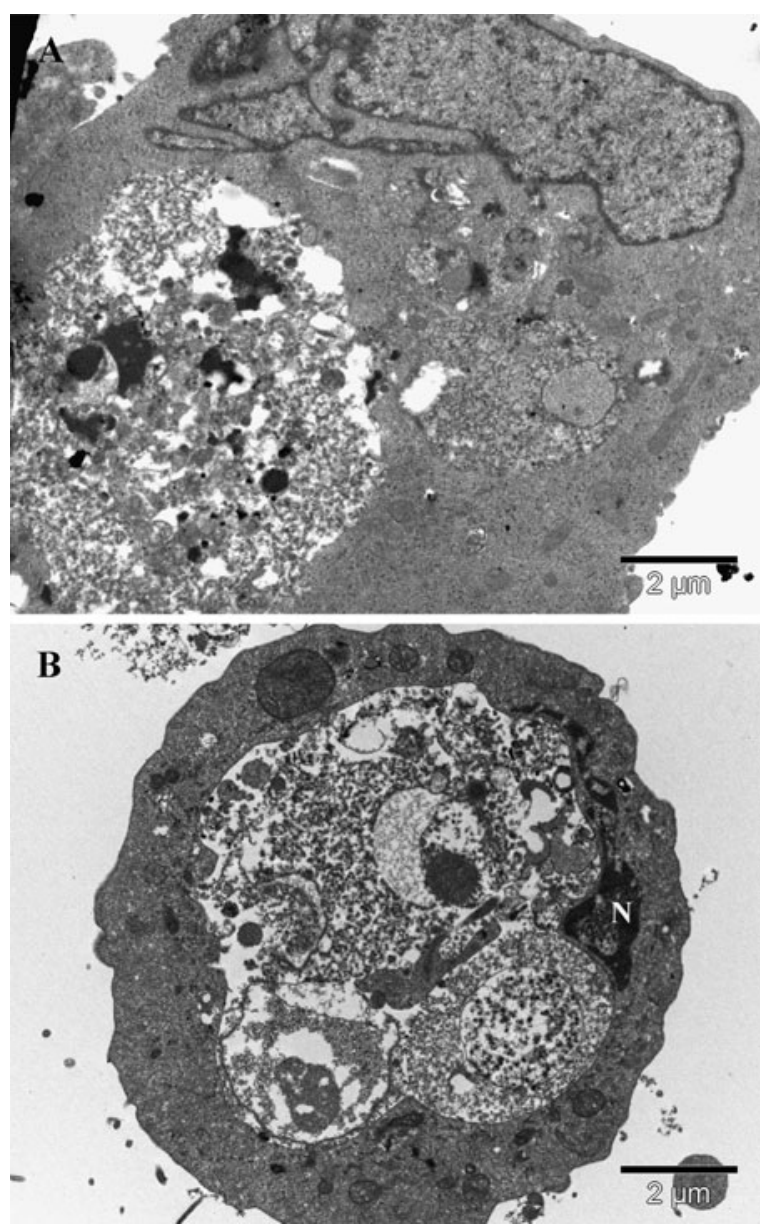

Fig. 4 Cell-in-cell phenomenon: Lcs from centenarians showing entire cells undergoing degeneration inside huge vacuoles. These figures, detectable after both RA (a) and 3MA (b) treatments, either with or without FCS, did not significantly differ from each other. $N$ indicates the nucleus of the cannibal cell those responsible for homo-cannibalism (which is present in Lcs from centenarians but not in those from adult people, before and after SRV).

First of all, we considered the expression of genes that resulted to be involved in autophagy according to previous reports (Overholtzer et al. 2007; Fiorentini et al. 2001). If we consider a significance threshold of $p<0.01$, none of these genes resulted to be present in group 1, while some of them resulted present in group 2 (Table 2). Furthermore, other genes resulted to be significantly different in both comparisons with a $p<0.05$ (Table 3). It is to note that most of the bestknown genes responsible for the autophagy machinery such as the ATG genes resulted not included in this list, indicating that their expression is not different in adult subjects and centenarians. This suggests that the observed difference between adult and old people in autophagic response and homocannibalic capacity likely relies more on signaling pathways rather than execution pathways. In addition, we also show 100 top-scoring genes (Supplementary Table 2) resulting from the comparisons "Centenarians basal vs. Centenarians starved"; "Adult basal vs. Adult starved"; "Centenarians basal vs. Adult basal"; "Centenarians starved vs. Adult starved", together with the volcano plots of each comparison (Supplementary Fig. 1).

We first analyzed KEGG pathways altered by starvation by comparing Lcs from adults or centenarians before and after starvation (Table 4). Twentyseven pathways resulted to be significantly affected by starvation (i.e., had a high number of genes significantly over- or under-expressed as compared with chance) in both Lcs from adults and from centenarians, 15 of them being shared by the two groups (indicated in italics). This suggests that starvation affects a common core of pathways shared by adults and centenarians, but also that many differences are present between them. Notably, in the group of adults, the pathway of insulin signaling and of ubiquitin-mediated proteolysis resulted affected by starvation, as one may expect, but not in the group of centenarians, suggesting that these subjects have a response to starvation stress that follows different strategies. We then performed the same analysis on the genes belonging to groups 1,2 , or 3 , with a KEGG annotation. The results are reported in Table 5, and pathways that have a role in the autophagy or, likely, cell cannibalism, are in italic. Interestingly, 
Fig. 5 "Time course" analysis of the cannibalic activity carried out by Lcs from centenarians: electron micrographs show a the "embrace" of the cannibalic cell to its "victim", b followed by the engulfment of the "victim", c, d the progressive digestion of the internalized cells, e finally leading to the dissolution of the ingested cell. (EC engulfing cell, $I C$ internalized cell, $D C$ digested cell)
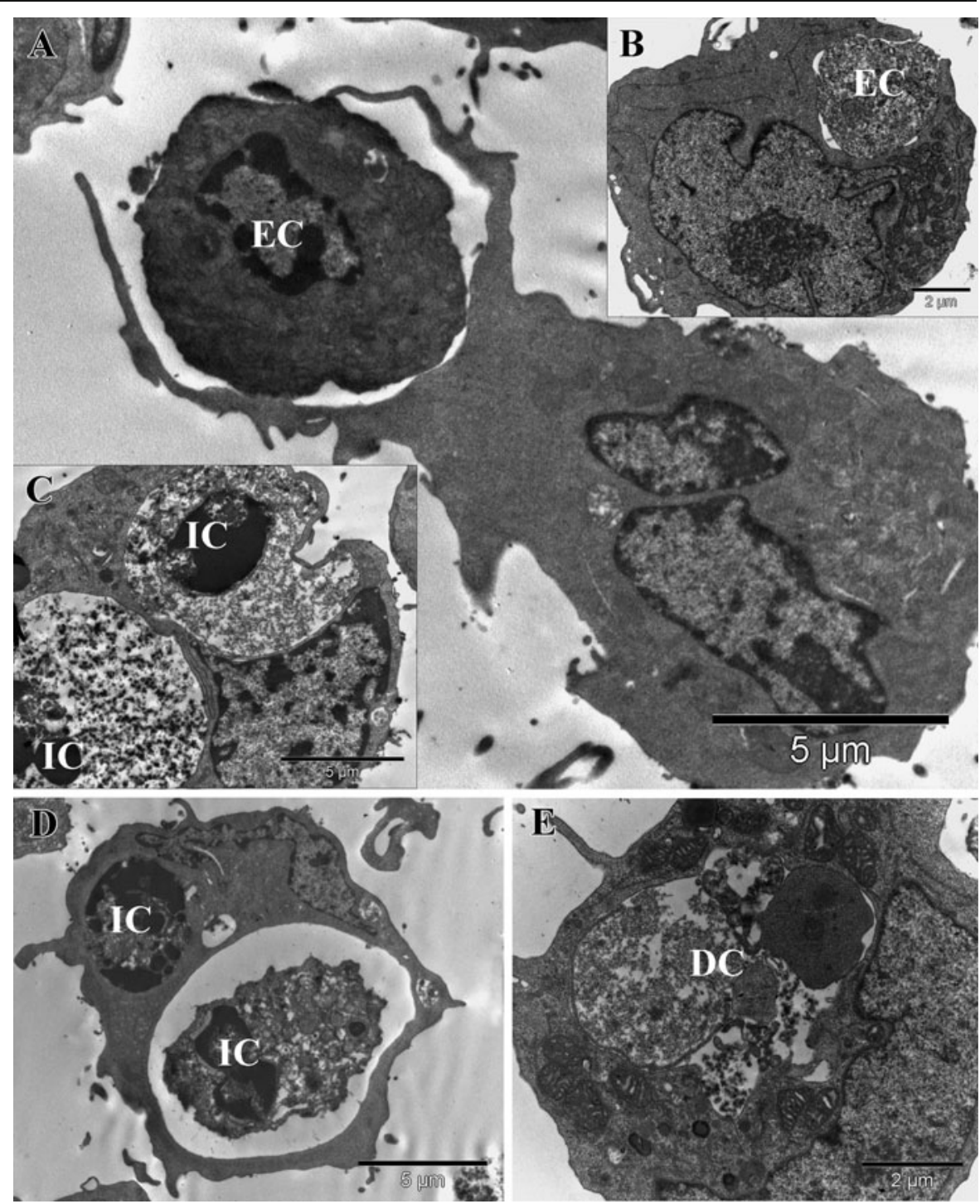

among the altered KEGG pathways, the one called "regulation of autophagy" containing the ATG genes is not present, whereas on the other side two important pathways for suppression of autophagy result to be altered, namely mTOR signaling and insulin signaling. We remark that, in our analysis, no post hoc correction for multiple analyses was applied, since it is known that aging does not have strong effects on gene expression patterns (de Magalhães et al. 2009). We could not exclude the possibility of false-positives, but, in this case, any typical correction (such as Bonferroni or Benjamini-Hochberg) that reduces the chance of false-positives would have been too conservative, resulting in only one significant pathway for each analysis. With less conservative thresholds, we observed a remarkable coherence between the morphological and functional analyses and the top-ranking pathways shown in this section.

For these pathways, we reported in Fig. 6 the probes that resulted to being highly altered $(p<0.01$ for groups 1 and 2; in panel 3, genes that are altered in group 3 with $p<0.05$ ). Significant genes of group 1 (Fig. 6a) suggest that Lcs from centenarians have a slower cell cycle (upregulation of CDKN1A/p21) and a higher resistance to apoptosis (downregulation of TP53, upregulation of MDM2). After starvation, a general decrease of Wnt signaling pathway, cell cycle, and tight-adherens junctions is observed in Lcs from centenarians with respect to Lcs from adult people (Fig. 6b). The same decrease of Wnt pathway was 
Table 2 Gene expression analysis (genes involved in autophagy that result to being differently expressed in Lcs from adult subjects and centenarians under starvation)

\begin{tabular}{|c|c|c|c|c|}
\hline Probe & Symbol & Description & $p$ value & LogRatio \\
\hline 1567527_at & - & Ubiquitin B (UBB) mRNA, 3' UTR and genetic suppressor element & 0.009 & 0.21 \\
\hline 215139_at & ARHGEF10 & Rho guanine nucleotide exchange factor (GEF) 10 & 0.006 & 0.2 \\
\hline 201084_s_at & BCLAF1 & BCL2-associated transcription factor 1 & 0.009 & -0.57 \\
\hline 205988_at & CD84 & CD84 molecule & 0.000 & 1.09 \\
\hline 210895_s_at & CD86 & CD86 molecule & 0.010 & 0.71 \\
\hline 214486_x_at & CFLAR & CASP8 and FADD-like apoptosis regulator & 0.009 & 0.71 \\
\hline 201769_at & CLINT1 & Clathrin interactor 1 & 0.002 & -1.22 \\
\hline 208749_x_at & FLOT1 & Flotillin 1 & 0.000 & 0.55 \\
\hline 210142_x_at & FLOT1 & Flotillin 1 & 0.007 & 0.43 \\
\hline 213056_at & FRMD4B & FERM domain containing 4B & 0.008 & 0.31 \\
\hline 35820_at & GM2A & GM2 ganglioside activator & 0.000 & 0.52 \\
\hline 212737_at & GM2A & GM2 ganglioside activator & 0.002 & 0.57 \\
\hline 226671_at & LAMP2 & Lysosomal-associated membrane protein 2 & 0.005 & -0.56 \\
\hline 209615_s_at & PAK1 & p21/Cdc42/Rac1-activated kinase 1 (STE20 homolog, yeast) & 0.007 & 0.24 \\
\hline 222569 at & UGCGL1 & UDP-glucose ceramide glucosyltransferase-like 1 & 0.002 & -0.54 \\
\hline
\end{tabular}

A $\log$ Ratio $>0$ means upregulation in centenarians

observed for group 3 (Fig. 6c). Genes significantly altered for insulin and mTOR pathway such as IGF-1, the regulatory subunit 5 of PI3K (PIK3R5), and SOCS3 are upregulated in centenarians, in agreement with the above described results indicating that Lcs from centenarians have a diminished induction of autophagy. Indeed, the silencing of SOCS3 knocked down mTOR and phospho-mTOR, and the recruitment of the mTOR upstream PI3K to the membrane is mediated via the non-catalytic p101 PIK3R5 subunit (Shao et al. 2010; Brock et al. 2003). Both genes as well as IGF1 appear to be upregulated in Lcs from centenarians. Finally, resistance to apoptosis of Lcs from centenarians increases after starvation, due to the upregulation of CFLAR. CFLAR (FLIP) also appears to inhibit autophagy by preventing Atg3 from binding and processing LC3 (Lee et al. 2009).

\section{Discussion}

In the present work, we describe for the first time striking findings obtained in lymphoid cells from centenarians: the ability of a subset of these cells to

Table 3 Gene expression analysis (genes involved in autophagy that result in being differently expressed in Lcs from adult subjects and centenarians both under basal conditions and starvation)

\begin{tabular}{|c|c|c|c|c|c|c|}
\hline Probe & Symbol & Description & $\begin{array}{l}p \text { value } 1 \\
\text { (basal) }\end{array}$ & $\begin{array}{l}\text { Basal centenarians } \\
\text { vs. adults }\end{array}$ & $\begin{array}{l}p \text { value } 2 \\
\text { (starvation) }\end{array}$ & $\begin{array}{l}\text { SRV centenarian vs. } \\
\text { adults }\end{array}$ \\
\hline 1552627_a_at & ARHGAP5 & $\begin{array}{l}\text { Rho GTPase activating } \\
\text { protein } 5\end{array}$ & 0.038099 & 0.57 & 0.003 & 0.91 \\
\hline 222343_at & BCL2L11 & $\begin{array}{l}\text { BCL2-like } 11 \text { (apoptosis } \\
\text { facilitator) }\end{array}$ & 0.038408 & 0.22 & 0.009 & 0.89 \\
\hline 200838_at & CTSB & cathepsin B & 0.012542 & 0.93 & 0.005 & 0.56 \\
\hline 1560031_at & FRMD4A & $\begin{array}{l}\text { FERM domain containing } \\
\text { 4A }\end{array}$ & 0.047776 & -1.82 & 0.003 & -2.1 \\
\hline 209727_at & GM2A & GM2 ganglioside activator & 0.014867 & 0.71 & 0.000 & 0.8 \\
\hline
\end{tabular}

A $\log$ Ratio $>0$ means upregulation in centenarians 
Table 4 KEGG pathways induced by starvation on Lcs from adults or centenarians

\begin{tabular}{|c|c|c|c|c|c|c|c|c|c|c|c|}
\hline \multicolumn{6}{|c|}{ Lcs from adult subjects } & \multicolumn{6}{|c|}{ Lcs from centenarians } \\
\hline Id & Pathway & $p$ value & Probes & Sign & Perc & Id & Pathway & $p$ value & Probes & Sign & Perc \\
\hline 100 & $\begin{array}{l}\text { Biosynthesis of } \\
\text { steroids }\end{array}$ & $2.33 E-15$ & 47 & 27 & 57.4468 & 970 & $\begin{array}{c}\text { Aminoacyl-tRNA } \\
\text { biosynthesis }\end{array}$ & $1.63 E-09$ & 72 & 21 & 29.1667 \\
\hline 900 & $\begin{array}{l}\text { Terpenoid } \\
\text { biosynthesis }\end{array}$ & $3.01 E-10$ & 26 & 16 & 61.5385 & 680 & $\begin{array}{l}\text { Methane } \\
\text { metabolism }\end{array}$ & 0.000180336 & 27 & 8 & 29.6296 \\
\hline 3060 & Protein export & $9.60 E-07$ & 20 & 11 & 55 & 750 & $\begin{array}{l}\text { Vitamin B6 } \\
\text { metabolism }\end{array}$ & 0.000327913 & 11 & 5 & 45.4545 \\
\hline 51 & $\begin{array}{l}\text { Fructose and } \\
\text { mannose } \\
\text { metabolism }\end{array}$ & $5.93 E-05$ & 125 & 28 & 22.4 & 100 & $\begin{array}{l}\text { Biosynthesis of } \\
\text { steroids }\end{array}$ & 0.000566365 & 47 & 10 & 21.2766 \\
\hline 750 & $\begin{array}{l}\text { Vitamin B6 } \\
\text { metabolism }\end{array}$ & 0.000352831 & 11 & 6 & 54.5455 & 260 & Glycine & 0.00100598 & 117 & 17 & 14.5299 \\
\hline 260 & Glycine & 0.000770544 & 117 & 24 & 20.5128 & 900 & $\begin{array}{l}\text { Terpenoid } \\
\text { biosynthesis }\end{array}$ & 0.00474231 & 26 & 6 & 23.0769 \\
\hline 520 & $\begin{array}{l}\text { Nucleotide sugars } \\
\text { metabolism }\end{array}$ & 0.000820956 & 42 & 12 & 28.5714 & 530 & $\begin{array}{l}\text { Aminosugars } \\
\text { metabolism }\end{array}$ & 0.00502183 & 62 & 10 & 16.129 \\
\hline 970 & $\begin{array}{c}\text { Aminoacyl-tRNA } \\
\text { biosynthesis }\end{array}$ & 0.000860945 & 72 & 17 & 23.6111 & 51 & $\begin{array}{l}\text { Fructose and } \\
\text { mannose } \\
\text { metabolism }\end{array}$ & 0.00515321 & 125 & 16 & 12.8 \\
\hline 530 & $\begin{array}{r}\text { Aminosugars } \\
\text { metabolism }\end{array}$ & 0.00130742 & 62 & 15 & 24.1935 & 3060 & Protein export & 0.00685102 & 20 & 5 & 25 \\
\hline 670 & $\begin{array}{l}\text { One carbon pool } \\
\text { by folate }\end{array}$ & 0.00281919 & 54 & 13 & 24.0741 & 5110 & Cholera-infection & 0.0187912 & 132 & 15 & 11.3636 \\
\hline 720 & $\begin{array}{l}\text { Reductive } \\
\text { carboxylate } \\
\text { cycle }\left(\mathrm{CO}_{2}\right. \\
\text { fixation) }\end{array}$ & 0.00600731 & 28 & 8 & 28.5714 & 670 & $\begin{array}{l}\text { One carbon pool } \\
\text { by folate }\end{array}$ & 0.0188968 & 54 & 8 & 14.8148 \\
\hline 680 & $\begin{array}{l}\text { Methane } \\
\text { metabolism }\end{array}$ & 0.0173025 & 27 & 7 & 25.9259 & 271 & $\begin{array}{l}\text { Methionine } \\
\text { metabolism }\end{array}$ & 0.0238625 & 46 & 7 & 15.2174 \\
\hline 604 & $\begin{array}{l}\text { Glycosphingolipid } \\
\text { biosynthesis- } \\
\text { ganglioseries }\end{array}$ & 0.0254198 & 42 & 9 & 21.4286 & 720 & $\begin{array}{l}\text { Reductive } \\
\text { carboxylate cycle } \\
\text { (CO } \mathrm{C}_{2} \text { fixation) }\end{array}$ & 0.0286859 & 28 & 5 & 17.8571 \\
\hline 5110 & $\begin{array}{l}\text { Cholera- } \\
\text { infection }\end{array}$ & 0.0297714 & 132 & 21 & 15.9091 & 604 & $\begin{array}{l}\text { Glycosphingolipid } \\
\text { biosynthesis- } \\
\text { ganglioseries }\end{array}$ & 0.0462643 & 42 & 6 & 14.2857 \\
\hline 271 & $\begin{array}{l}\text { Methionine } \\
\text { metabolism }\end{array}$ & 0.0433791 & 46 & 9 & 19.5652 & 520 & $\begin{array}{l}\text { Nucleotide sugars } \\
\text { metabolism }\end{array}$ & 0.0462643 & 42 & 6 & 14.2857 \\
\hline 510 & $\begin{array}{l}N \text {-Glycan } \\
\text { biosynthesis }\end{array}$ & 4.41E-05 & 92 & 23 & 25 & 4110 & Cell cycle & 0.000400009 & 305 & 35 & 11.4754 \\
\hline 31 & $\begin{array}{l}\text { Inositol } \\
\text { metabolism }\end{array}$ & 0.000206133 & 7 & 5 & 71.4286 & 790 & Folate biosynthesis & 0.0044163 & 91 & 13 & 14.2857 \\
\hline 4620 & $\begin{array}{l}\text { Toll-like receptor } \\
\text { signaling } \\
\text { pathway }\end{array}$ & 0.000832524 & 225 & 39 & 17.3333 & 20 & $\begin{array}{l}\text { Citrate cycle (TCA } \\
\text { cycle) }\end{array}$ & 0.00873996 & 67 & 10 & 14.9254 \\
\hline 4662 & $\begin{array}{l}\text { B cell receptor } \\
\text { signaling } \\
\text { pathway }\end{array}$ & 0.00275638 & 179 & 31 & 17.3184 & 272 & $\begin{array}{l}\text { Cysteine } \\
\text { metabolism }\end{array}$ & 0.0107765 & 49 & 8 & 16.3265 \\
\hline 4120 & $\begin{array}{l}\text { Ubiquitin- } \\
\text { mediated } \\
\text { proteolysis }\end{array}$ & 0.00297313 & 165 & 29 & 17.5758 & 300 & $\begin{array}{l}\text { Lysine } \\
\text { biosynthesis }\end{array}$ & 0.015692 & 9 & 3 & 33.3333 \\
\hline 4910 & $\begin{array}{l}\text { Insulin signaling } \\
\text { pathway }\end{array}$ & 0.00473197 & 408 & 59 & 14.4608 & 310 & Lysine degradation & 0.0184726 & 120 & 14 & 11.6667 \\
\hline 1510 & $\begin{array}{l}\text { Neurodegenerative } \\
\text { disorders }\end{array}$ & 0.0171052 & 125 & 21 & 16.8 & 72 & $\begin{array}{l}\text { Synthesis and } \\
\text { degradation of } \\
\text { ketone bodies }\end{array}$ & 0.0235023 & 18 & 4 & 22.2222 \\
\hline 5030 & Amyotrophic & 0.0206436 & 68 & 13 & 19.1176 & 5120 & Epithelial cell & 0.0238141 & 210 & 21 & 10 \\
\hline
\end{tabular}


Table 4 (continued)

\begin{tabular}{|c|c|c|c|c|c|c|c|c|c|c|c|}
\hline \multicolumn{6}{|c|}{ Lcs from adult subjects } & \multicolumn{6}{|c|}{ Lcs from centenarians } \\
\hline Id & Pathway & $p$ value & Probes & Sign & Perc & Id & Pathway & $p$ value & Probes & Sign & Perc \\
\hline & $\begin{array}{l}\text { lateral sclerosis } \\
\text { (ALS) }\end{array}$ & & & & & & $\begin{array}{l}\text { signaling in } \\
\text { Helicobacter } \\
\text { pylori infection }\end{array}$ & & & & \\
\hline 1030 & $\begin{array}{l}\text { Glycan structures } \\
\text { - biosynthesis } 1\end{array}$ & 0.0211521 & 288 & 41 & 14.2361 & 450 & $\begin{array}{l}\text { Selenoamino acid } \\
\text { metabolism }\end{array}$ & 0.0350763 & 83 & 10 & 12.0482 \\
\hline 4130 & $\begin{array}{l}\text { SNARE } \\
\text { interactions in } \\
\text { vesicular } \\
\text { transport }\end{array}$ & 0.0256267 & 107 & 18 & 16.8224 & 650 & $\begin{array}{l}\text { Butanoate } \\
\text { metabolism }\end{array}$ & 0.0364154 & 107 & 12 & 11.215 \\
\hline 1032 & $\begin{array}{c}\text { Glycan structures } \\
\text {-degradation }\end{array}$ & 0.0318253 & 72 & 13 & 18.0556 & 4612 & $\begin{array}{l}\text { Antigen processing } \\
\text { and presentation }\end{array}$ & 0.0385715 & 208 & 20 & 9.61538 \\
\hline 561 & $\begin{array}{l}\text { Glycerolipid } \\
\text { metabolism }\end{array}$ & 0.0424621 & 145 & 22 & 15.1724 & 500 & $\begin{array}{l}\text { Starch and sucrose } \\
\text { metabolism }\end{array}$ & 0.0436591 & 147 & 15 & 10.2041 \\
\hline
\end{tabular}

Gene expression before and after starvation of Lcs from adult subjects or centenarians was considered. Genes differently expressed with a $p<0.05$ were considered. In italic: pathways shared by the two age groups

Probes number of genes involved in the pathway according to KEGG database for which a probe is present in the genechip, Sign number of genes differently expressed before and after starvation, Perc percentage of altered genes with respect to the total number of genes involved in the pathway

exert a homo-cannibalic (HC) fratricidal behavior. This behavior was undetectable in cells from adult subjects and was apparently characterized by: (1) the ability of these cells to engulf and digest in huge vacuoles entire cells and by the fact that (2) victims of these executioners were their siblings, generally degenerating siblings; (3) this phagic behavior appeared increased by SRV but unrelated to self-phagic behavior, i.e., to autophagy, and, finally that, according to the KEGG pathway analysis, as conceivable, (4) a complex framework of different molecular pathways was involved this behavior. Among these pathways are cytoskeletal and anti-apoptotic pathways.

Although described in literature since many years, the process called cell-in-cell xenophagy, xenocannibalism, or entosis recently emerged from literature as an intriguing inter-cellular interaction phenomenon that may derive from a huge series of physiological and pathological conditions (Overholtzer et al. 2007; Overholtzer and Brugge 2008; Lai et al. 2010; Mailleux et al. 2008; Qian and Shi 2009). From a finalistic point of view, two different hypotheses emerged from literature: one is that this peculiar cell-cell "interaction" could be due to a metabolic stress and could provide "food" to cells lacking of nutrients (cannibalism) (Matarrese et al. 2008). The second is referred as to the ability of certain cells that, once detached from their substrate, i.e., from the extracellular matrix, enter the cytoplasm or invade other cells in order to suicide themselves (Overholtzer et al. 2007). Hence, these two processes mirror diverse endpoints for the cell: survival or death. The mechanisms implicated in these processes are far from being elucidated. The following actors have been taken into consideration in the mechanisms leading to cell-in-cell phenomenon: (a) extracellularly released molecules, e.g., cathepsin B and metallothionein-2A; (b) cell surface molecules such as integrins, cadherins, and glycosphingolipids; (c) components of cytoskeletal network and their regulators, such as the actomyosin-mediated contractile force and the small GTPases of the Rho family (Overholtzer et al. 2007; Lai et al. 2010; Fiorentini et al. 2001). Furthermore, as mentioned above, (d) the autophagic machinery was apparently involved (Malorni et al. 2007). Possibly, all these elements, together, form a complex framework leading to cell-in-cell phenomenon. However, the specificity, if any, of this mechanism is far from being elucidated. In fact, either signaling molecules, i.e., the eat-me signals, or intracellular machinery, e.g., the cross-talk with autophagic process and lysosomal compartment function, are still under investigation. The results reported in this work add 
Table 5 KEGG pathway significance analysis

\begin{tabular}{|c|c|c|c|c|c|c|}
\hline Group & Id & Pathway & $p$ value & Probes & SignProbes & Percentage \\
\hline \multirow[t]{10}{*}{$1^{\mathrm{a}}$} & 4110 & Cell cycle & 0.000 & 305 & 29 & 9.51 \\
\hline & 3010 & Ribosome & 0.001 & 237 & 23 & 9.70 \\
\hline & 531 & Glycosaminoglycan degradation & 0.002 & 48 & 8 & 16.67 \\
\hline & 240 & Pyrimidine metabolism & 0.007 & 211 & 19 & 9.00 \\
\hline & 1032 & Glycan structures-degradation & 0.008 & 72 & 9 & 12.50 \\
\hline & 670 & One carbon pool by folate & 0.015 & 54 & 7 & 12.96 \\
\hline & 4210 & Apoptosis & 0.018 & 232 & 19 & 8.19 \\
\hline & 630 & Glyoxylate and dicarboxylate metabolism & 0.035 & 26 & 4 & 15.38 \\
\hline & 5220 & Chronic myeloid leukemia & 0.038 & 269 & 20 & 7.43 \\
\hline & 5214 & Glioma & 0.043 & 239 & 18 & 7.53 \\
\hline \multirow[t]{10}{*}{$2^{b}$} & 100 & Biosynthesis of steroids & 0.000 & 47 & 13 & 27.66 \\
\hline & 5110 & Cholera-Infection & 0.002 & 132 & 17 & 12.88 \\
\hline & 900 & Terpenoid biosynthesis & 0.003 & 26 & 6 & 23.08 \\
\hline & 4530 & Tight junction & 0.005 & 426 & 38 & 8.92 \\
\hline & 4330 & Notch signaling pathway & 0.019 & 144 & 15 & 10.42 \\
\hline & 4670 & Leukocyte transendothelial migration & 0.026 & 358 & 30 & 8.38 \\
\hline & 5216 & Thyroid cancer & 0.026 & 111 & 12 & 10.81 \\
\hline & 4110 & Cell cycle & 0.030 & 305 & 26 & 8.52 \\
\hline & 4310 & Wnt signalling pathway & 0.044 & 450 & 35 & 7.78 \\
\hline & 4520 & Adherens junction & 0.047 & 333 & 27 & 8.11 \\
\hline \multirow[t]{16}{*}{$3^{c}$} & 4940 & Type I diabetes mellitus & 0.000 & 141 & 7 & 4.96 \\
\hline & 5212 & Pancreatic cancer & 0.001 & 252 & 9 & 3.57 \\
\hline & 4650 & Natural killer cell mediated cytotoxicity & 0.002 & 356 & 10 & 2.81 \\
\hline & 4612 & Antigen processing and presentation & 0.004 & 208 & 7 & 3.37 \\
\hline & 750 & Vitamin B6 metabolism & 0.005 & 11 & 2 & 18.18 \\
\hline & 4210 & Apoptosis & 0.007 & 232 & 7 & 3.02 \\
\hline & 5214 & Glioma & 0.009 & 239 & 7 & 2.93 \\
\hline & 4010 & MAPK signalling pathway & 0.009 & 792 & 15 & 1.89 \\
\hline & 4630 & Jak-STAT signaling pathway & 0.014 & 391 & 9 & 2.30 \\
\hline & 4910 & Insulin signalling pathway & 0.018 & 408 & 9 & 2.21 \\
\hline & 4370 & VEGF signaling pathway & 0.018 & 214 & 6 & 2.80 \\
\hline & 4150 & mTOR signalling pathway & 0.018 & 156 & 5 & 3.21 \\
\hline & 4664 & Fc epsilon RI signalling pathway & 0.025 & 232 & 6 & 2.59 \\
\hline & 5218 & Melanoma & 0.027 & 235 & 6 & 2.55 \\
\hline & 4310 & Wnt signaling pathway & 0.031 & 450 & 9 & 2.00 \\
\hline & 5220 & Chronic myeloid leukemia & 0.047 & 269 & 6 & 2.23 \\
\hline
\end{tabular}

Pathways that have a role in the autophagy or, likely, cell cannibalism, are in italic

${ }^{a}$ Pathways significantly changed only in the comparison adult vs. centenarians in basal culture conditions (group 1)

${ }^{b}$ Pathways significantly changed only in the comparison adult vs. centenarians under starvation (group 2)

${ }^{\mathrm{c}}$ Pathways significantly changed in both comparisons (group 3)

some new insight in this scenario. More precisely, an important point is that only cells obtained from centenarians but not those from adult (and old; data not shown here) subjects were capable of displaying the $\mathrm{HC}$ activity. A second point stems from the absence of any regulatory activity by the 
Fig. 6 Genes with altered expression in the KEGG pathway analysis (see Table 2). a Genes differently expressed in KEGG pathways altered in group $1(p<0.01)$; b genes differently expressed in KEGG pathways altered in group $2(p<0.01)$; c genes differently expressed in KEGG pathways altered in group $3(p<0.05$ in both comparisons). LogRatio $>0$ : upregulation in Les from centenarians; $\operatorname{LogRatio}<0$ : upregulation in Lcs from adult people
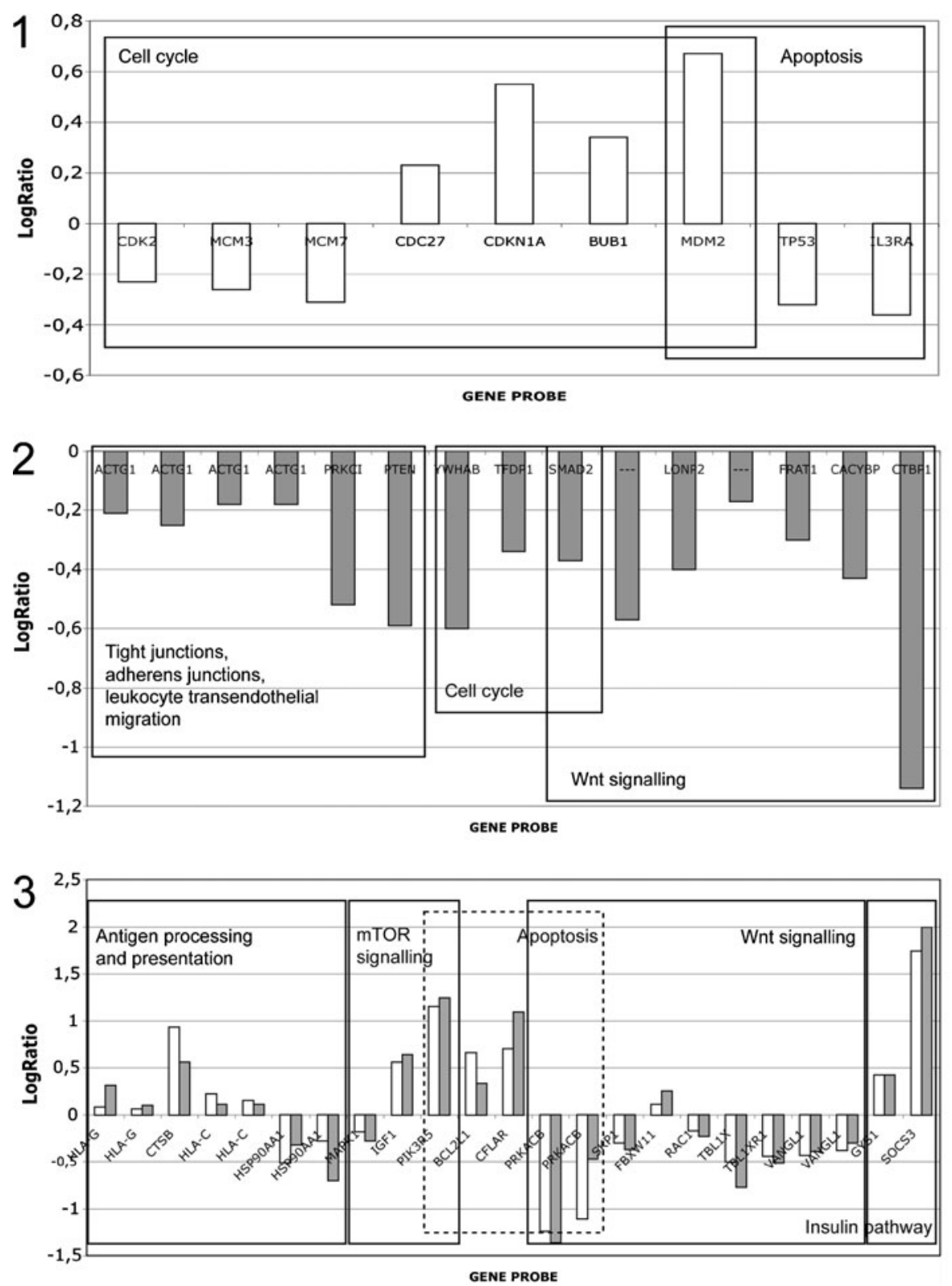

autophagy-modulating drugs RA (a mTOR complex 1 inhibitor) and 3-MA (which results in autophagy inhibition due to suppression of class III PtdIns 3-kinase) on the process. The third insight derived from gene expression analyses that claim for the implication in homo-cannibalism of different actors mentioned above $(\mathrm{a}-\mathrm{d})$.

The fact that only cells from centenarians (lymphoid cell lines from three different subjects) were capable of exerting $\mathrm{HC}$ could give rise to some intriguing hypotheses. In fact, "healthy" centenarians should be considered as a "super-selected" population, and their immune system is known to display a series of peculiar features including resistance to oxidative stress and to apoptotic stimulation and the ability to survive in unfavorable environmental conditions in comparison with cells from healthy adult or old subjects, the so-called successful aging (Monti et al. 2000; Ostan et al. 2008). Hence, HC detectable in these cells could be of some relevance in the powerful survival ability detectable in lymphocytes from these subjects. In addition, since immortalized lymphocytes 
are CD19 B cells (see Supplementary Table 1), the $\mathrm{HC}$, besides representing a bizarre behavior for this cell lineage, could also have some further implication: (1) we cannot rule out the possibility that $\mathrm{HC}$ could lead to the survival of certain subsets of B lymphocytes and to the homeostasis of the immune system of centenarians; (2) we can hypothesize that $\mathrm{HC}$, as happens for autophagic processes, could be implicated in antigen processing and presentation, e.g., in a modulatory activity directly targeted to APC (Franceschi et al. 2005; Alberti et al. 2006; Münz 2010). Finally, (3) on the basis of literature data suggesting that centenarians display a characteristic autoantibody profile, i.e., the absence of organspecific auto-antibodies and an increase in nonorgan-specific auto-antibodies without any fullblown autoimmune disease (Lisa et al. 2009), we can also hypothesize that $\mathrm{HC}$ could interfere with the onset or the development of auto-reactive cell clones and with autoimmunity helping to attain longevity. However, although the general rules of immunosenescence are still matter for debate, the implication of such cell behavior in assuring immune system longevity could be of importance, i.e., together with autophagy, it may provide a formidable cytoprotection pathway.

In addition, the cross-talk between self- and xeno-cannibalism should be taken into consideration. We expected, in fact, on the basis of our previous works, that, upon triggering the autophagic processes by serum withdrawal and/or by using mTOR inhibitor RA, HC could be improved (Matarrese et al. 2008; Malorni et al. 2007). The idea that HC could represent an exacerbation of the autophagic process was in fact conceivable. Strikingly instead, no significant variation was detected after treatment with RA. Also, the use of the prototypical autophagy inhibitor 3-MA did not influence $\mathrm{HC}$ behavior. Hence, we can hypothesize that the two processes can follow two intertwined but separate signalling pathways. In fact, the lysosomal compartment is certainly involved in both autophagy and $\mathrm{HC}$ but, on the basis of our results with RA and 3-MA, the two processes appear as somewhat separate. Unfortunately, although a more selective modulation of autophagy, e.g., via siRNA, could be fruitful, the simultaneous presence in the same culture medium of "victims" and "executioners" clearly hampers these analyses.
In line with the above hypothesis, the results obtained from genetic analyses seem to indicate that single genes, and some KEGG pathways as well, are brought into play and can contribute to HC. Among the first there are: (1) the extracellularly released proteases such as cathepsin $\mathrm{B}$, whose activity was previously demonstrated as mandatory in order that the HC could be exerted; (2) some cell surface molecules such as integrins and cadherins, that, together with glycosphingolipids, have already been demonstrated to contribute to cell-in-cell interaction; (3) the components of cytoskeletal network, including actin binding proteins and small GTPases of the Rho family (Overholtzer et al. 2007). These molecules, which are permanently activated in metastatic cells, have been suggested to confer a phagocytic behavior to non-professional phagocytes (Fiorentini et al. 2001). Among the KEGG pathways, wnt signaling pathway, an essential contributor of cell migration and actin cytoskeleton remodeling and polarization, appears as prominent (Lai et al. 2009).

A further point to be mentioned concerns the EBVinduced immortalization. The EBV, the human herpes virus 4 , is a virus of the herpes family associated with certain cancers (Martin and Gutkind 2008). Hence, we cannot rule out the possibility that our results could derive from the EBV infection and that, as happens in cancer cells, this can be referred as to the so-called cell immortalization process. In this case, an important point remains obscure: Since cells from adult subjects did not display HC, why only immortalized cells from centenarians should exert the $\mathrm{HC}$ behavior?

In conclusion, the study of cell-in-cell phenomenon, particularly homo-cannibalism, is still in its infancy, and many questions remain unanswered (e.g., Panková et al. 2010). A more precise determination of the cannibal cell subsets and the molecular mechanisms associated with the phenomenon are urgently needed. In fact, although obtained in EBV-immortalized lymphoid cell lines and undetectable in freshly isolated B cells (data not shown), in line with literature, we cannot exclude the possibility that our results could be of general interest in different fields of investigation, including cancer and immunology.

Acknowledgements This work was partially supported by: the Italian Ministry of Health and Ministry of Instruction, University, and Research (FIRB RBIP067F9E and Reti FIRB RBPR05NWWC_006) to WM; the Italian Ministry of Health, 
Progetto Ricerca Finalizzata 2008, convenzione 35: “An integrated approach to identify functional, biochemical and genetic markers for diagnostic and prognostic purposes in the elderly, in the centenarians and in people with dementia, Alzheimer's disease, mild cognitive impairment" to CF; Roberto and Cornelia Pallotti Legacy for Cancer Research Grants to CF and SS. ETE is a BioPharmaNet fellow (www.biopharmanet.eu) and this work is in partial fulfillment of the requirement for the BioPharmaNet Genomics and Biosensors research projects.

Open Access This article is distributed under the terms of the Creative Commons Attribution Noncommercial License which permits any noncommercial use, distribution, and reproduction in any medium, provided the original author(s) and source are credited.

\section{References}

Alberti S, Cevenini E, Ostan R, Capri M, Salvioli S, Bucci L, Ginaldi L, De Martinis M, Franceschi C, Monti D (2006) Age-dependent modifications of type 1 and type 2 cytokines within virgin and memory CD4+ $\mathrm{T}$ cells in humans. Mech Ageing Dev 127:560-566

Biederbick A, Kern HF, Elsässer HP (1995) Monodansylcadaverine (MDC) is a specific in vivo marker for autophagic vacuoles. Eur J Cell Biol 66:3-14

Boya P, Gonzalez-Polo RA, Poncet D, Andreau K, Vieira HL, Roumier T, Perfettini JL, Kroemer G (2003) Mitochondrial membrane permeabilization is a critical step of lysosomeinitiated apoptosis induced by hydroxychloroquine. Oncogene 22:3927-3936

Boya P, Gonzalez-Polo RA, Casares N, Perfettini JL, Dessen P, Larochette N, Métivier D, Meley D, Souquere S, Yoshimori T, Pierron G, Codogno P, Kroemer G (2005) Inhibition of macroautophagy triggers apoptosis. Mol Cell Biol 25:1025-1040

Brock C, Schaefer M, Reusch HP, Czupalla C, Michalke M, Spicher K, Schultz G, Nürnberg B (2003) Roles of G beta gamma in membrane recruitment and activation of p110 gamma/p101 phosphoinositide 3-kinase gamma. J Cell Biol 160:89-99

Chen S, Rehman SK, Zhang W, Wen A, Yao L, Zhang J (2010) Autophagy is a therapeutic target in anticancer drug resistance. Biochim Biophys Acta 1806:220-229

Codogno P, Meijer AJ (2005) Autophagy and signaling: their role in cell survival and cell death. Cell Death Differ 12:1509-1518

de Magalhães JP, Curado J, Church GM (2009) Meta-analysis of age-related gene expression profiles identifies common signatures of aging. Bioinformatics 25:875-881

Fiorentini C, Falzano L, Fabbri A, Stringaro A, Logozzi M, Travaglione S, Contamin S, Arancia G, Malorni W, Fais S (2001) Activation of rho GTPases by cytotoxic necrotizing factor 1 induces macropinocytosis and scavenging activity in epithelial cells. Mol Biol Cell 12:2061-2073

Franceschi C, Olivieri F, Marchegiani F, Cardelli M, Cavallone L, Capri M, Salvioli S, Valensin S, De Benedictis G, Di Iorio A, Caruso C, Paolisso G, Monti D (2005) Genes involved in immune response/inflammation, IGF1/insulin pathway and response to oxidative stress play a major role in the genetics of human longevity: the lesson of centenarians. Mech Ageing Dev 126:351-361

Giovannini C, Matarrese P, Scazzocchio B, Sanchez M, Masella R, Malorni W (2002) Mitochondria hyperpolarization is an early event in oxidized low-density lipoprotein-induced apoptosis in Caco-2 intestinal cells. FEBS Lett 523:200-206

Kroemer G, Reed JC (2000) Mitochondrial control of cell death. Nat Med 6:513-519

Lai SL, Chien AJ, Moon RT (2009) Wnt/Fz signaling and the cytoskeleton: potential roles in tumorigenesis. Cell Res 19:532-545

Lai Y, Lim D, Tan PH, Leung TK, Yip GW, Bay BH (2010) Silencing the metallothionein $2 \mathrm{~A}$ gene induces entosis in adherent MCF-7 breast cancer cells. Anat Rec (Hoboken) 93:1685-1691

Lee JS, Li Q, Lee JY, Lee SH, Jeong JH, Lee HR, Chang H, Zhou FC, Gao SJ, Liang C, Jung JU (2009) FLIPmediated autophagy regulation in cell death control. Nat Cell Biol 11:1355-1362

Levine B (2005) Eating oneself and uninvited guests: autophagy-related pathways in cellular defense. Cell 120:159-162

Lisa A, Monti D, Franceschi C, Scovassi AI (2009) Autoantibodies to poly (ADP-ribose) polymerase in centenarians: a reappraisal of Grabar's hypothesis. Gerontology 55:427429

Madeo F, Tavernarakis N, Kroemer G (2010) Can autophagy promote longevity? Nat Cell Biol 12:842-846

Mailleux AA, Overholtzer M, Brugge JS (2008) Entosis, a cell death process related to cell cannibalism between tumor cells. Med Sci Paris 24:246-248

Malorni W, Matarrese P, Tinari A, Farrace MG, Piacentini M (2007) Xeno-cannibalism: a survival "escamotage". Autophagy 3:75-77

Marini M, Lapalombella R, Canaider S, Farina A, Monti D, De Vescovi V, Morellini M, Bellizzi D, Dato S, De Benedictis G, Passarino G, Moresi R, Tesei S, Franceschi C (2004) Heat shock response by EBV-immortalized B-lymphocytes from centenarians and control subjects: a model to study the relevance of stress response in longevity. Exp Gerontol 39:83-90

Martin D, Gutkind JS (2008) Human tumor-associated viruses and new insights into the molecular mechanisms of cancer. Oncogene 2:S31-S42

Matarrese P, Gambardella L, Cassone A, Vella S, Cauda R, Malorni W (2003) Mitochondrial membrane hyperpolarization hijacks activated $\mathrm{T}$ lymphocytes toward the apoptotic-prone phenotype: homeostatic mechanisms of HIV protease inhibitors. J Immunol 170:6006-6015

Matarrese P, Ciarlo L, Tinari A, Piacentini M, Malorni W (2008) Xeno-cannibalism as an exacerbation of selfcannibalism: a possible fruitful survival strategy for cancer cells. Curr Pharm Des 14:245-252

Mehrpour M, Esclatine A, Beau I, Codogno P (2010) Autophagy in health and disease. 1. Regulation and significance of autophagy: an overview. Am J Physiol Cell Physio 1298:C776-C785

Monti D, Salvioli S, Capri M, Malorni W, Straface E, Cossarizza A, Botti B, Piacentini M, Baggio G, Barbi 
C, Valensin S, Bonafè M, Franceschi C (2000) Decreased susceptibility to oxidative stress-induced apoptosis of peripheral blood mononuclear cells from healthy elderly and centenarians. Mech Ageing Dev 121:239-250

Moreau K, Luo S, Rubinsztein DC (2010) Cytoprotective roles for autophagy. Curr Opin Cell Biol 22:206-211

Mormone E, Matarrese P, Tinari A, Cannella M, Maglione V, Farrace MG, Piacentini M, Frati L, Malorni W, Squitieri F (2006) Genotype-dependent priming to self- and xenocannibalism in heterozygous and homozygous lymphoblasts from patients with Huntington's disease. J Neurochem 98:1090-1099

Münz C (2010) Antigen processing via autophagy—not only for MHC class II presentation anymore? Curr Opin Immunol 22:89-93

Narendra D, Tanaka A, Suen DF, Youle RJ (2009) Parkininduced mitophagy in the pathogenesis of Parkinson disease. Autophagy 5:706-708

Olivieri F, Bonafè M, Giovagnetti S, Stecconi R, Cardelli M, Cavallone L, Spazzafumo L, Marchegiani F, Carrieri G, Mugianesi E, Giampieri C, Centurelli M, Moresi R, Tesei S, Lisa R, Viticchi C, Falsetti L, Salvioli S, Franceschi C (2003) In vitro IL-6 production by EBV-immortalized B lymphocytes from young and elderly people genotyped for $-174 \mathrm{C} / \mathrm{G}$ polymorphism in IL-6 gene: a model to study the genetic basis of inflamm-aging. Mech Ageing Dev 124:549-553

Orvedahl A, Levine B (2008) Viral evasion of autophagy. Autophagy 4:280-285

Ostan R, Bucci L, Capri M, Salvioli S, Scurti M, Pini E, Monti D, Franceschi C (2008) Immunosenescence and immunogenetics of human longevity. Neuroimmunomodulation 15:224240

Overholtzer M, Brugge JS (2008) The cell biology of cell-incell structures. Nat Rev Mol Cell Biol 9:796-809
Overholtzer M, Mailleux AA, Mouneimne G, Normand G, Schnitt SJ, King RW, Cibas ES, Brugge JS (2007) A nonapoptotic cell death process, entosis, that occurs by cell-in-cell invasion. Cell 131:966-979

Panková K, Rösel D, Novotný M, Brábek J (2010) The molecular mechanisms of transition between mesenchymal and amoeboid invasiveness in tumor cells. Cell Mol Life Sci 67:63-71

Perl A, Gergely P Jr, Nagy G, Koncz A, Banki K (2004) Mitochondrial hyperpolarization: a checkpoint of T-cell life, death and autoimmunity. Trends Immunol 25:360-367

Qian Y, Shi Y (2009) Natural killer cells go inside: entosis versus cannibalism. Cell Res 19:1320-1321

Salvioli S, Capri M, Tieri P, Loroni J, Barbi C, Invidia L, Altilia S, Santoro A, Pirazzini C, Pierini M, Bellavista E, Alberghina L, Franceschi C (2008) Different types of cell death in organismal aging and longevity: state of the art and possible systems biology approach. Curr Pharm Des 14:226-236

Sansoni P, Vescovini R, Fagnoni F, Biasini C, Zanni F, Zanlari L, Telera A, Lucchini G, Passeri G, Monti D, Franceschi C, Passeri M (2008) The immune system in extreme longevity. Exp Gerontol 43:61-65

Shao RX, Zhang L, Peng LF, Sun E, Chung WJ, Jang JY, Tsai WL, Hyppolite G, Chung RT (2010) Suppressor of cytokine signaling 3 (SOCS3) suppresses hepatitis $\mathrm{C}$ virus replication in an mTOR-dependent manner. J Virol 84:6060-6069

Simonsen A, Tooze SA (2009) Coordination of membrane events during autophagy by multiple class III PI3-kinase complexes. J Cell Biol 186:773-782

Tinari A, Matarrese P, Minetti M, Malorni W (2008) Hyperphagia by self- and xeno-cannibalism: cell death by indigestion?: a reminiscence of the Phedrus Fabula "Rana Rupta et Bos"? Autophagy 4:128-130

Yang Z, Klionsky DJ (2010) Eaten alive: a history of macroautophagy. Nat Cell Biol 2:814-822 